\title{
Evaluation of the tutoring program of the Colegio Primitivo y Nacional de San Nicolás de Hidalgo on the tutoring program in times of Covid-19 pandemic: student opinion
}

\section{Evaluación del programa de tutoría del Colegio Primitivo y Nacional de San Nicolás de Hidalgo sobre el programa de tutoría en tiempos de pandemia por Covid-19: opinión del estudiante}

\author{
SESENTO, Leticia*†'\& LUCIO, Rodolfo"“ \\ 'Colegio Primitivo y Nacional de San Nicolás de Hidalgo, Mexico. \\ "Universidad Michoacana de San Nicolás de Hidalgo, Faculty of Veterinary Medicine and Zootechnics, Mexico.
}

ID $1^{\text {st }}$ Author: Leticia, Sesento / ORC ID: 0000-0002-6456058X, Researcher ID Thomson: S-6997-2018, CVU CONACYT ID: 449302

ID $1^{\text {st }}$ Co-author: Rodolfo, Lucio / ORC ID: 0000-0002-0535-3652, Researcher ID Thomson: X-2391-2018, CVU CONACYT ID: 947303

DOI: $10.35429 / J H E W .2021 .8 .5 .1 .6$

Received January 10, 2021; Accepted June 30, 2021

\begin{abstract}
Tutoring is a strategy to contribute to the development of skills and support students in solving academic problems; help in the promotion of their autonomy and comprehensive training, as well as contribute to improving their academic performance through adequate personalized and group guidance. In addition to implementing it in the educational center, it is important to evaluate it to know the perspective, progress and improvements for each school year, taking into account the needs of the student population. In the present, the results of a survey applied to 375 young people are presented to know their perception of the mentoring program of this cycle under the virtual modality due to the COVID-19 pandemic. Some of the specific results show that: $74 \%$ consider that attending tutorials benefited their adaptation to academic life. Regarding whether the tutoring sessions have helped them to better understand the services that the Universidad Michoacana de San Nicolás de Hidalgo provides to students, $87 \%$ consider that they met this objective. And on whether they consider that the activities aimed at integration (workshops, tutorials, etc.) are sufficient, $81 \%$ consider that they are. The above shows a general satisfaction with the sessions, schedules, the attention received, the topics, etc.
\end{abstract}

Tutoring, Evaluation, Upper secondary, PIT, Student

\begin{abstract}
Resumen
La tutoría es una estrategia para contribuir al desarrollo de las competencias y apoyar a los alumnos en la resolución de problemas de tipo académico; coadyuvar en la promoción de su autonomía y formación integral, así como contribuir a mejorar su rendimiento académico mediante la adecuada orientación personalizada y de grupo. Es importante además de implementarla en el centro educativo, evaluarla para conocer la perspectiva, avances y mejoras para cada ciclo escolar, tomando en cuenta las necesidades de la población estudiantil. En el presente se presentan los resultados de una encuesta aplicada a 375 jóvenes para conocer su percepción del programa de tutoría del presente ciclo bajo la modalidad virtual debido a la pandemia por COVID-19. Algunos de los resultados específicos muestran que: un $74 \%$ consideran que el asistir a tutorías benefició su la adaptación a la vida académica. Sobre si las sesiones de tutoría les han ayudado a conocer mejor los servicios que la Universidad Michoacana de San Nicolás de Hidalgo presta a los estudiantes, el $87 \%$ considera que si cumplió este objetivo. Y Sobre si consideran que las actividades encaminadas a la integración (Talleres, tutorías, etc.) son suficientes el $81 \%$ considera que lo son. Lo anterior, muestra una satisfacción en general con las sesiones, horarios, la atención recibida, los temas, etc.
\end{abstract}

Citation: SESENTO, Leticia \& LUCIO, Rodolfo. Evaluation of the tutoring program of the Colegio Primitivo y Nacional de San Nicolás de Hidalgo on the tutoring program in times of Covid-19 pandemic: student opinion. Journal-Health Education and Welfare. 2021. 5-8:1-6.

\footnotetext{
* Correspondence to Author (Email: leticiasesentogarcia@yahoo.com.mx).

$\uparrow$ Researcher contributing as first author.
} 


\section{Introduction}

The challenges of Higher Secondary Education (EMS) in our country are concentrated in three indicators: dropout, failure and terminal efficiency, this situation reflects the need for these Institutions to carry out studies on the characteristics and behavior of the student population, in relation to the factors that influence their educational trajectory, such as entry, permanence, graduation and degree. To have a positive impact on them, some strategies have been designed within the framework of the Comprehensive Reform of Higher Secondary Education (RIEMS), among which the tutorial support stands out, constituted as a curricular support in the Higher Secondary Education System of the Michoacana University of San Nicolás de Hidalgo.

Tutoring is a strategy to contribute to the development of skills and support students in solving academic problems; help in the promotion of their autonomy and comprehensive training, as well as contribute to improving their academic performance through adequate personalized and group guidance. This will allow the student to play a more active role in the teaching-learning process; promote the creation and recreation of knowledge and develop abilities, skills and attitudes, in the academic aspect in favor of their permanence in Higher Secondary Education. That is why it is important, in addition to implementing it in the educational center, to evaluate it to know the perspective, progress and improvements for each school year, taking into account the needs of the student population.

\section{Growth}

\section{Theoretical framework}

\section{What is tutoring?}

At the beginning of the XXI century, the National Association of Universities and Institutions of Higher Education (2001: 23) proposed a definition of tutoring indicated as: "a process of accompaniment during the training of students, which is specified through personalized attention to a student or a reduced group of students, on the part of competent and trained academics for this function, conceptually relying on the theories of learning rather than on those of teaching" (p. 23).
In Mexico, this definition had a great impact and can be considered as the "official" definition of tutoring in higher education.

Arbizu Bakaikoa, Lobato Fraile and del Castillo (2005: 8) defined tutoring as "a formative intervention action aimed at monitoring students and which is considered one more teaching activity".

For their part, De la Cruz Flores, García Campos and Abreu Hernández (2006: 1367) describe it as the "formative process of a sociocognitive nature, personalized and aimed at turning novices into competent individuals, through their integration into communities of practice (Wenger, 2001) and networks of experts, who solve problems in dynamic and complex environments, create and recreate professional action and, where appropriate, generate advanced knowledge".

Herrera Aponte (2006: 200-201) exposes it as a "dialectical, interaction, intersubjective process, where feelings and knowledge converge in a game of emotions and language [...] Mentoring as an accompaniment process is a task of commitments and responsibilities shared [...] To be successful, trust, communication, understanding and respect from both parties must be combined".

\section{Importance of evaluation in tutoring}

It is important to consider that the typical objects of the tutorial evaluation are: "the students; the teaching and administrative staff; the curriculum; teaching materials; the programs; projects and institutions".

Regarding the tutorial activity, the evaluation should allow obtaining information from those who participate directly in the development of the Tutorial Action Plan, that is, the tutors, the tutored students and the tutoring coordinators, so aspects related to the tutorial action for each of these actors, in order to have sufficient elements to visualize the process from different perspectives and in its entirety (Morales, s / f). 
But the reality is that currently, in this evaluation, the most usual thing in institutions is that the use of the tutor is only evaluated in an objective way through qualifications or progress, and self-evaluation is used to evaluate the tutor, which consists of collect direct information from tutors active in the program, which provides relevant data for decisionmaking and allows, in some cases, teachers and coordinators to carry out a self-assessment based on objectivity and self-criticism.

\section{Institutional Tutoring Program of the Colegio Primitivo y Nacional de San Nicolás de Hidalgo}

The tutoring department was implemented in the Primitive and National School of San Nicolás de Hidalgo in 2007, which only worked individual tutoring, and began with eight teachers, who, in order to act as tutors, must take a diploma that accredits them to carry out the tutorial function, due to the large number of students, the tutors were insufficient and that was when group tutoring began to be implemented and tutoring was stopped in 2009.

In 2012 the Tutoring Coordination returned to work, with an already defined program, defined functions of the tutor, in addition, it began with 13 teachers who act as tutors; In addition, the peer tutoring provided by students providing social services from the Faculty of Psychology is implemented, which favors to increase the number of students served, in addition to providing another space to the most trusted young people, which is reflected in attending the courses that are carried out.

Currently, there is already an established format to evaluate tutoring from the perspective of the teacher and the student, which will allow to continue with the improvements and each cycle the actions to be carried out on topics of interest to the students are increased, among which Study techniques, learning styles, group integration, time planning, motivation and life plan are mainly addressed. It is expected to begin to implement talks on academic stress and a course to work on intellectual development, which will be taught with the support of the students of the Faculty of Psychology. The sessions are held one hour a week directed by the social service providers and coordinated by the responsible teacher.

\section{General objective}

Know the student's perception of the Tutoring program in the COVID-19 pandemic stage.

\section{Specific objectives:}

Analyze the context of young people based on their virtual tutoring sessions.

Identify areas of opportunity to
strengthen.

Know the topics of interest to young people for future sessions.

\section{Methodology}

It is a descriptive research using Likert scale surveys. To carry out this research, an instrument designed by the Coordination was applied to 375 students between 14 and 19 years old, of which 224 are women and 150 men.

\section{Instrument description}

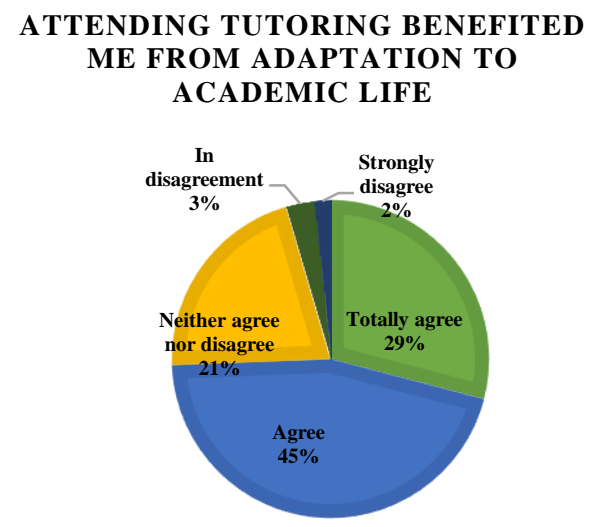

Graphic 1

An instrument designed by coordinating 10 Likert scale items and an open question about their topics of interest was used.

\section{Analysis of results}

Analyzing the instrument, the following was obtained:

Regarding whether they consider that the distribution (Organization of groups, timing, etc.) of the tutorials has been appropriate, $93 \%$ consider that it has been (adding completely in agreement and in agreement).

SESENTO, Leticia \& LUCIO, Rodolfo. Evaluation of the tutoring program of the Colegio Primitivo y Nacional de San Nicolás de Hidalgo on the tutoring program in times of Covid19 pandemic: student opinion. Journal-Health Education and Welfare. 2021 
HAS THE DISTRIBUTION (GROUP ORGANIZATION, TIMING, ETC.) OF THE TUTORING BEEN APPROPRIATE

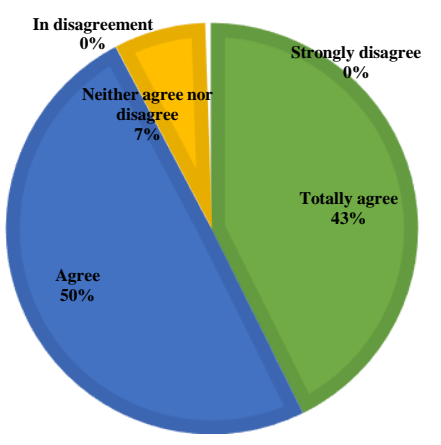

Graphic 2

Regarding whether they consider that the Student-Student relationship developed normally, $72 \%$ of them think that it did (adding completely in agreement and in agreement).

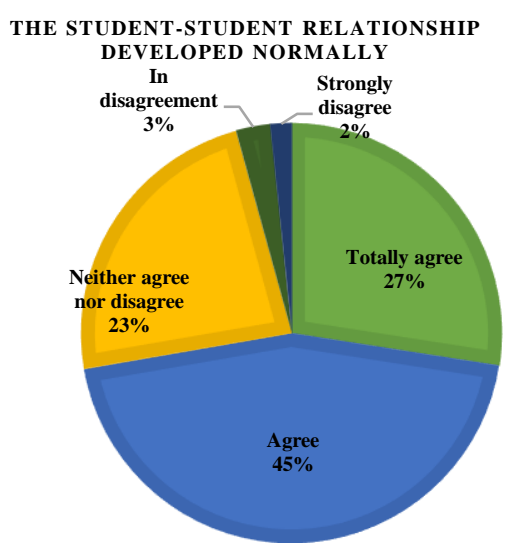

Graphic 3

Regarding whether they consider that attending tutorials benefited their adaptation to academic life, their opinion was that, $74 \%$ if they consider that they obtained that benefit (adding completely agree and agree).

When asked, if the tutoring sessions have helped them to better understand the services that the Universidad Michoacana de San Nicolás de Hidalgo provides to students, $87 \%$ consider that if they met this objective (adding completely in agreement and agreement).

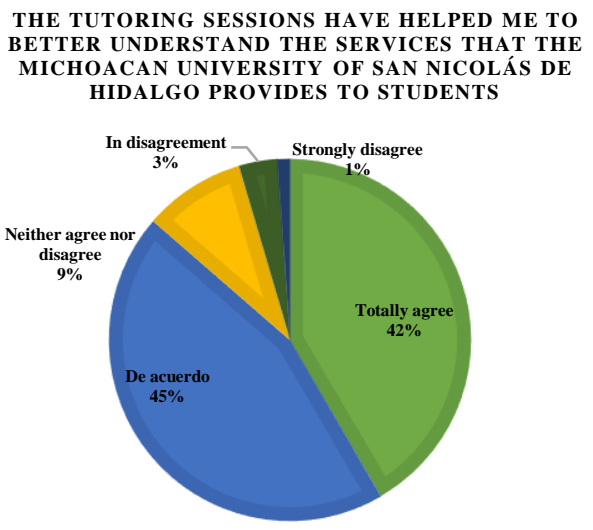

Graphic 4

Regarding whether the schedule is appropriate for their interests and needs, 77\% consider that it is (adding completely agree and agree).

Depending on whether they consider themselves to be globally satisfied with the tutoring sessions, 89\% are (adding completely in agreement and in agreement).

\section{AM GLOBALLY SATISFIED WITH THE TUTORING SESSIONS}

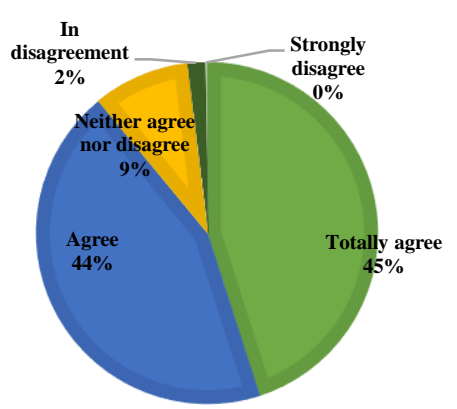

\section{Graphic 5}

Regarding whether they consider that the activities aimed at integration (workshops, tutorials, etc.) are sufficient, $81 \%$ consider that they are (adding completely in agreement and agreement).

\begin{tabular}{l|r|r|}
$\begin{array}{l}\text { The activities aimed at integration } \\
\text { (workshops, tutorials, etc.) are } \\
\text { sufficient }\end{array}$ & No. Percentage \\
\hline Totally agree & 108 & $28.80 \%$ \\
\hline Agree & 194 & $51.73 \%$ \\
\hline Neither agree nor disagree & 63 & $16.80 \%$ \\
\hline In disagreement & 6 & $1.60 \%$ \\
\hline Strongly disagree & 4 & $1.07 \%$ \\
\hline Sum of totals & 375 & $100.00 \%$ \\
\hline
\end{tabular}

Table 1 
Regarding whether they consider that the coordinators of the tutorial project have been at their disposal in its development, 91\% consider that they have been (adding completely in agreement and in agreement).

\begin{tabular}{|l|r|r|}
$\begin{array}{l}\text { The coordinators of the tutorial } \\
\text { project have been at our disposal } \\
\text { in its development }\end{array}$ & No. Percentage \\
\hline Totally agree & 171 & $45.60 \%$ \\
\hline Agree & 168 & $44.80 \%$ \\
\hline Neither agree nor disagree & 32 & $8.53 \%$ \\
\hline In disagreement & 3 & $0.80 \%$ \\
\hline Strongly disagree & 1 & $0.27 \%$ \\
\hline Sum of totals & 375 & $100.00 \%$ \\
\hline
\end{tabular}

Table 2

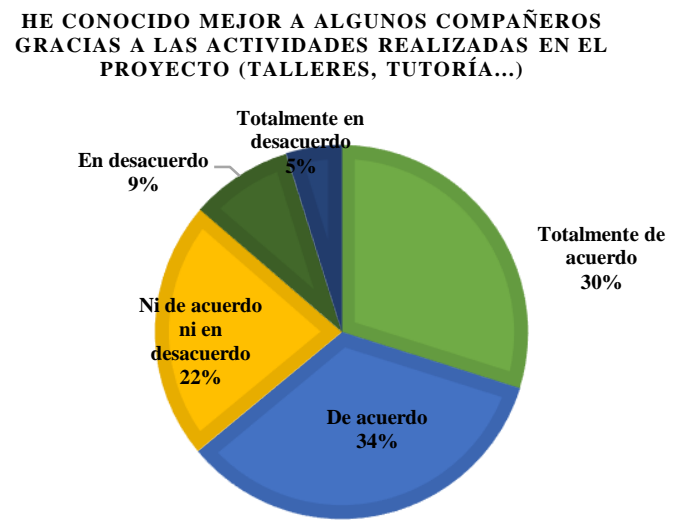

Graphic 6

When asked, if they believe that the teachers who have taught them this year were coordinated with the tutorial project, $71 \%$ of them consider that this coordination does exist (adding completely in agreement and in agreement).

\begin{tabular}{|l|r|r|}
\hline $\begin{array}{c}\text { I think that the teachers who have } \\
\text { taught me this year were } \\
\text { coordinated with the tutorial } \\
\text { Project }\end{array}$ & No. Percentage \\
\hline Totally agree & 106 & $28.27 \%$ \\
\hline Agree & 161 & $42.93 \%$ \\
\hline Neither agree nor disagree & 85 & $22.67 \%$ \\
\hline In disagreement & 17 & $4.53 \%$ \\
\hline Strongly disagree & 6 & $1.60 \%$ \\
\hline Sum of totals & 375 & $100.00 \%$ \\
\hline
\end{tabular}

Table 3

When asking if the digital platform Classroom, enabled for the project, has been useful for different aspects, $78 \%$ consider it appropriate (adding completely agree and agree).
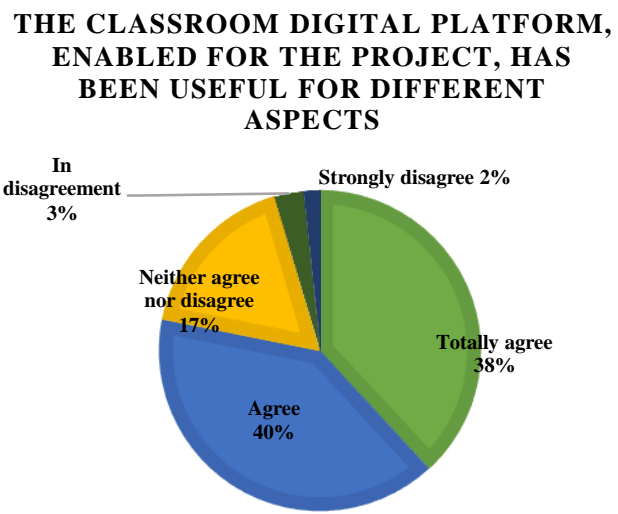

Graphic 7

When asked if they think they have gotten to know some colleagues better thanks to the activities carried out in the project (Workshops, tutoring ...), 64\% believe that they did support them (adding completely in agreement and in agreement).

THE TUTORING SCHEDULE HAS ADAPTED TO YOUR INTERESTS AND NEEDS

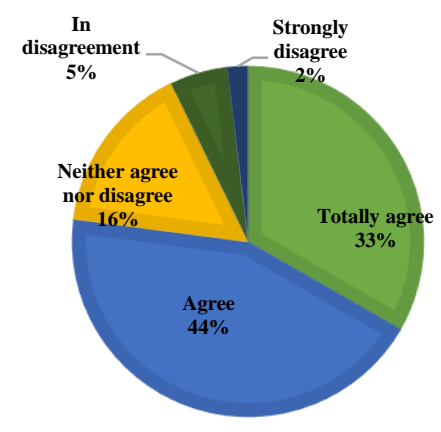

Graphic 8

In addition to the above results, the students were asked, what topics they would like to address in the tutoring sessions to find out their current needs and concerns, and the main ones were:

Self-esteem.

Capabilities.

Anxiety.

Vocational orientation.

Eating disorders.

Managing emotions.

Decision making.

Sexuality.

SESENTO, Leticia \& LUCIO, Rodolfo. Evaluation of the tutoring program of the Colegio Primitivo y Nacional de San Nicolás de Hidalgo on the tutoring program in times of Covid19 pandemic: student opinion. Journal-Health Education and Welfare. 2021 


\section{Conclusions}

The previous results allow us to deduce that a constant evaluation of the program is important to detect areas of opportunity, and above all to know the context with which we are working, especially during this pandemic it was important to know if the measures taken by the coordination were considered appropriate In the voice of the young people, the results show us a general satisfaction with the program, its sessions, coordination, schedules and group management. It is important to highlight that the adaptation has been favorable to continue offering this educational service to young people and it is observed that the design and execution has been appropriate for the context. In general, the perception of young people is positive and the objectives set out in the Institutional Tutoring Program about bringing them closer to the dynamics of the school, providing them with learning strategies and promoting group and institutional integration are met. Regarding the topics that they propose to be addressed at other times, it is important to consider them for future sessions, since they are situations that affect young people and can affect their performance and therefore their permanence in the institution.

The evaluation of the development of the tutorial activity is essential, since, as in any other educational action implemented, we must have objective information about its usefulness and incorporate corrective measures that allow the development and that tend to increase the effectiveness of the actions that are performed.

The design of evaluation forms should be based on the identification of indicators that clearly show the progress of the program. In the case of the Colegio Primitivo y Nacional de San Nicolás de Hidalgo, indicators are proposed based both on the bibliographic review and on the needs detected on the fly.

\section{References}

Arbizu, F., Lobato, C., y Del Castillo, L. (2005). Algunos modelos de abordaje de la tutoría universitaria. Revista de Psicodidáctica, 10(1), 7- 21. Recovered from: http://dialnet.unirioja.es/servlet

/articulo?codigo $=1222702$
Asociación Nacional de Universidades e Instituciones de Educación Superior. (2001). Programas Institucionales de Tutoría. Una propuesta de la ANUIES para su organización y funcionamiento en las instituciones de educación superior (Segunda Edición.). México, D.F.: ANUIES

De la Cruz Flores, G., García Campos, T. y Abreu, L. F. (2006). Modelo integrador de la tutoría: de la dirección de tesis a la sociedad del conocimiento. Revista Mexicana de Investigación Educativa, 11(31), 1363-1388. Recovered from: http://dialnet.unirioja.es/servlet/articulo?codigo $=2323338$

Herrera, M. T. (2006). El proceso de tutoría. Un ritual a la esperanza. EDUCARE, 10(3), 192201. Recovered from: http://revistas.upel.edu.ve/index. php/educare/article/view/145

Morales, N., Góngora, E. (s/f). Evaluación de la Tutoría en la Universidad Autónoma de Yucatán. Ponencia. 